Article received on March $13^{\text {th }} 2017$

Article accepted on March $15^{\text {th }} 2017$

UDC: 781.7(497.115)"'19/20"'

\author{
Mirjana Zakić* \\ Department of Ethnomusicology \\ Faculty of Music \\ Unversity of Arts in Belgrade \\ Sanja Rankovic** \\ Department of Ethnomusicology \\ Faculty of Music \\ Unversity of Arts in Belgrade
}

\title{
CURRENT MUSIC AND DANCE PRACTICE OF CENTRAL KOSOVO AND METOHIJA: TRANSFORMATIONS SINCE THE 1990s
}

\begin{abstract}
Ethnomusicological and ethnochoreological research of the central part of Kosovo and Metohija has been conducted since the late $19^{\text {th }}$ century up to the present. However, the gathered data are sparse and provide insufficient (and only partial) information regarding the music and dance tradition of this area. This fact was the main motive for arranging our own field-trip to the region, during 2015 and 2016.

The recorded material and numerous informants' narratives provided an important insight into the state of both previous and contemporary music and dance practice, enabling one to examine the transformations regarding music and dance that have taken place since the 1990s from several viewpoints: national and multinational, professional and amateur, local and regional. The causes of the changes that have occurred over the course of the last few decades, will be discussed in this paper through the political, ideological, socio-
\end{abstract}

* Author contact information: mira. zakic@gmail.com

** Author contact information:sanjaetno@gmail.com 
logical, and cultural prism. Thus, our attention will focus particularly on the national ensembles Shota (Priština) and Venac (Gračanica), as well as on the local repertoire of different ethnic groups - Serbian, Albanian, Romani and Croatian, in former and contemporary conditions. An especially intriguing question is to what extent, and in what ways did geopolitical restructuring and cultural evaluations in the post-socialist period influence the sustainability, i.e. the change in music and dance forms, as important aspects of the self-representation of the ethnicities that exist in this region?

Key words: music and dance practice, Kosovo and Metohija, transformations from the 1990s, national and multinational, inter-ethnic cultural resistance

Initial fieldwork in the domain of music and dance in Kosovo and Metohija were conducted from the late $19^{\text {th }}$ to the mid- $20^{\text {th }}$ century, ${ }^{1}$ at first by composers, pedagogues, and folklorists, and then also by some of the pioneers of ethnomusicology and ethnochoreology in Serbia. ${ }^{2}$ For the most part, this body of research encompassed the folk heritage of the area's ethnic Serbs, mostly of rural and, to a lesser degree, urban provenance, in accordance with the ruling spirit of the time, predicated on the romanticist heritage of searching for 'roots' and the need to affirm national culture. ${ }^{3}$ By contrast, the results of music and dance research undertaken since the mid- $20^{\text {th }}$ century indicate a refocusing on the folk heritage of the different ethnic communities living in Kosovo and Metohija, not only the Serbs, ${ }^{4}$ but also the Gorani people, ${ }^{5}$ Albanians, ${ }^{6}$ and Romani (Roma) people. ${ }^{7}$

The folk-music and dance heritage of central Kosovo and Metohija has seen the least amount of scholarly research. That was one of the reasons why we directed our own fieldwork in 2015-2016 at this part of the province. ${ }^{8}$ The area is located in the central part of the Kosovo Basin, or Valley - between Vučitrn and Uroševac. ${ }^{9}$ In our fieldwork, we covered the following urban and rural multiethnic communities: Gračanica, Priština, Ajvalija, Čaglavica, Livađe, Dobrotin, Kuzmin, Rabovce, Ugljare, Sušica, Laplje Selo, Lepina, Gornja Bitina, Donja Bitina, Gušterica, Brnjica, Plemetina, and Suvi Do.

The researched area is now populated by ethnic Albanians, Serbs, Romani, Turks, and Croats; Muslims, Orthodox, and Catholic Christians. Changes in the demographic makeup of this territory may be traced from the mid- $16^{\text {th }}$ century on, when, according to written testimonies, cultural heritage, and place names, Christians formed the most dominant ethnic group by far. ${ }^{10}$ The changes occurred due to various historical, political, and ideological circumstances and geopolitical developments: the exodus of ethnic Serbs following the Austro-Turkish wars of the late $17^{\text {th }}$ century, forced Islamisation and then also Albanisation of Kosovo's ethnic Serbs, mass immigration of ethnic Albanians, especially following the Congress of Berlin of $1878,{ }^{11}$ the discrimination of ethnic Serbs in political 
and public life under communist rule and their gradual expulsion, which was especially prominent during the violent breakup of Yugoslavia starting in 1991 and culminating with the NATO aggression of 1999. The expulsion of the ethnic Serbian population from their homes resulted in the near-total domination of the Albanian ethnic community. ${ }^{12}$ After 1999, Kosovo's ethnic Serbs (almost) entirely left certain urban communities, such as, in central Kosovo and Metohija, Priština and Lipljan. The ethnic structure of Janjevo, known as the village in Kosovo populated by ethnic Croats, has likewise shifted in favour of the Albanian ethnic community, since its population fled to Croatia. ${ }^{13}$ The villages of the Kosovo Valley that are still populated by ethnic Serbs are not grouped together, but scattered across the territory, side by side with ethnic Albanian villages and thus function like ghettoes (or ethnic enclaves). Following the expulsion of the ethnic Serbs from Priština, a part of that population moved to Gračanica, which became the administrative and cultural centre of the ethnic Serb community. All the institutions that are important for the functioning of ethnic Serbs in this part of Kosovo and Metohija are located in Gračanica.

On the basis of historical facts and the information we gathered in our fieldwork, it is clear that the breakup of Yugoslavia in 1991 and the NATO bombing campaign of 1999 were decisive events in the emergence of entirely new social and cultural relations in Kosovo and Metohija. They were the culmination of the disappearance of a state and a communist ideology that imposed atheism, Brotherhood and Unity, and an illusory notion of equality among all of its different nations and ethnicities [narodi $i$ narodnosti]. The causes of the changes that occurred after the 1990s are essentially political, religious, and, more broadly, ideological, and may also be observed in the respective cultural contexts of the various ethnic communities living in Kosovo and Metohija.

Our initial idea was to include all ethnic communities in our research, which proved difficult to do, due to our own national identity. Namely, following the tumultuous political events of the 1990s, the two authors of this study were the first ethnomusicologists who decided to conduct ethno-musicological research in the multiethnic character of central Kosovo and Metohija. However, we had no access to Albanian homes; we had been warned about this by the management of the Albanian national ensemble Shota, who told us that the time was not yet ripe for that kind of Serbian-Albanian cooperation. That is why our Albanian interlocutors comprised only former and current leaders of the ensemble: Dilaver Kryeziu, Shefqet Gjocaj, and Ylber Asllanaj, who were kind enough to provide us with important information about the activities of their institution, as well as the musical and dance repertoires of the Albanian population. Unfortunately, we were likewise unable to establish cooperation with representatives of the Turkish ethnic community, although we made numerous (but ultimately 
futile) appointments to interview members of the ethnic Turkish youth folklore society Gerçeא Derneği from Priština, led by Y1ldıray Bayram. Establishing contact with the Romani community was easier, but not as much as we expected, because the Romani nowadays mostly focus on modern musical expression.

\section{Restructuring: The Establishment of Two National Ensembles (Shota and Venac)}

The politico-ideological dimension of those changes is most pronounced when one considers the founding, activities, and repertoires of the two professional national ensembles that are active in Kosovo and Metohija today: Shota and Venac. The narrative of those two institutions is also a narrative about the relationship of culture and politics in Kosovo and Metohija over the past 50 years, as well as the relationship between national identity and music. Following the Second World War, in the Socialist Federal Republic of Yugoslavia (SFRY), a number of professional state ensembles were founded and charged with fostering the music and dance heritage of Yugoslavia's various nations and ethnicities. In addition to Kolo, Lado, and Tanec, a fourth professional ensemble, Shota, was inaugurated in March 1964. It was founded as a state institution, by the Assembly of the Autonomous Province of Kosovo and Metohija. In the heginning, the ensemble was multiethnic, with a programming policy that involved dances and choreographies of the various nations and ethnicities living in Kosovo and Metohija. However, due to political instability in Kosovo and Metohija, politically motivated ethnic Albanian members left the ensemble in 1991. In 1993, Shota was renamed Venac and until 1999, the ensemble employed ethnic Serbs and Romani (mostly in the orchestra). Its programming retained its multiethnic character.

Following the NATO bombing campaign of 1999, Serbs were forced out of Priština and the Serbian part of the ensemble thus had to leave not only the premises of Venac, but also Kosovo and Metohija itself. They were temporarily relocated to Niš (where they were hosted by the ensemble "Oro") until 2003, when they returned to Kosovo and Metohija. After difficulties with finding premises to work in, the ensemble was allowed to use the premises of the Cultural Centre in Gračanica. In 1999, ethnic Albanian artists resumed their activities in the Priština headquarters of the state ensemble, renaming it back to Shota. Thus, the partition was completed of a formerly unified multiethnic institution into two national ensembles: Serbian - Venac and Albanian - Shota.

From its foundation until the collapse of Yugoslavia, Shota employed ethnic Albanians, Serbs, and Romani. According to Dilaver Kryeziu, in the beginning, two thirds of the ensemble's repertoire comprised Albanian dance and music, with the remaining third comprising the folklore of other ethnicities (Serbs, Ro- 
Zakić, M. and Ranković, S.: Current Music and Dance Practice of Central Kosovo...

mani, and Turks). Its multiethnic repertoire was a trademark of Shota until 1991 and then also Venac until 1999, which, with a reduced ensemble, continued to perform parts of the old repertoire: Serbian dances, dances of the Bunjevci people, dances from Prizren, Romani dances from Kosovo and Metohija, dances from Kosaonica, etc.

The partition into two national ensembles also produced different programme orientations. For the most part, both ensembles perform dance choreographies from various parts of Kosovo and Metohija, but Shota performs only Albanian, whereas Venac performs only Serbian dances.

Currently, Shota employs 26 dancers (13 dance couples), eight instrumentalists, and four permanent vocal soloists. The orchestra comprises two clarinets, two accordions, and one def [daf], tupan [lodra], guitar, and double bass. The ensemble's staff structure does not include specific posts for players of traditional instruments, which means that these instruments are played by members of the ensemble orchestra who normally play classical instruments, while the ensemble occasionally hires players of traditional instruments from elsewhere. The ensemble's programming policy boils down to performing mostly stylised traditional music and dances, such as Rugovo dances, dances from the regions of Dukagjin and Karadak, etc. Since 2000, the ensemble's repertoire has also featured works by choreographers from Albania, such as dances from Tirana. The new management intend to work on new choreographies, which will represent all the regions of Kosovo, as well as to introduce a permanent choral group, for the sake of achieving a more rounded, as they put it, 'symphonised' sonority.

Over the past few years, the repertoire of Venac has comprised Serbian dances and songs from Kosovo and Metohija: dances from Peć, from the regions of Kosovo Pomoravlje, Prizren..., as well as from other parts of Serbia. In addition to the Youth Ensemble in Gračanica, comprising 26 dancers (13 dance couples), and only four instrumentalists (accordion and rhythm section), who are complemented for more important performances with musicians from Niš, in 2014 Venac established five children's ensembles in central Kosovo and Metohija. Their intense efforts in their present conditions, which we witnessed ourselves, are to a large extent the result of the extraordinary commitment on the part of their leader, Snežana Jovanović.

These two ensembles function in complete mutual isolation, without inviting each other to their concerts and celebrations. The number of their performances every year, both in Serbia and abroad (mostly in the region) is much smaller than the number of concerts Shota gave every year until the 'conflict years', because, as they freely admit, the financial side of their activities is a lot more difficult now. Also, within Kosovo and Metohija, the audiences of Venac comprise only ethnic Serbs, while Shota perform only for ethnic Albanians. 


\section{The Cultural Persistence and Multicultural Particularism of Kosovo's Local Communities}

The practice of multi-generational gatherings at Serbian dance parties in central Kosovo and Metohija remained topical from the 1970s to the 1990s. Those dance parties were sometimes also attended by Romani people. Accompanied by guitars, accordions, and drums, ${ }^{14}$ the dances included the čocke, shota, and Turkish-style dances (alaturka / allaturca). ${ }^{15}$

Prior to 1990, the Albanians also danced Serbian dances in their gatherings (Čačak, Zavrzlama, Špsko kolo, Moravac...), but then switched to Albanian dances only (such as shota, Deli Agush, Presheva, Mahama, Memeti, Ibrahim Hoxha, kalaçojna, teshko oro etc., accompanied by various kinds of instrumental ensembles, dominated by zurnas, citelijas, kavals, tapans, etc.).

Until the 1990s, local Romani brass bands, 'zurla and goc' ensembles, as well as ensembles dominated by 'klanets' and 'ćemane' were active participants at Serb, Romani, and Albanian weddings. Their repertoire was diverse, multiethnic, and regionally inflected (according to our informants, the most popular dances at the time were čačak, Žikino kolo, moravac, gilanka (gnjilanka), pembe, gajda (from the region of Skopje), Bulgarian dances, talava (a soloist dance), ${ }^{16}$ Eleno mome, čoček, duj duj, paro horo (a 'heavy dance', teško kolo), ki Priština, and shota), since, as they explain, 'It was not important at the time whether you were Serb, Romani, or Albanian'. ${ }^{17}$ However, after 1999, during their years of exile, which they spent mostly in Western European countries, the Romani, as they told us themselves, 'familiarised themselves for the first time with Muslim holidays and accepted the basic precepts of Islam', which they explain as follows: 'Before, we didn't know what that Quran was all about, but now it has become trendy among us, Romani people'. ${ }^{18}$ Their identification with Islamic ideology, along with celebrating Eid al-Adha [Kurban bajram], has caused them to stop celebrating vasilica and Saint George's Day [Đurdevdan] and to establish closer cooperation with the Albanian community, while distancing themselves from the Serbs still living in those parts.

As for Serbian church weddings and the musical ensembles and traditional dance repertoires that typically accompany them, we had an opportunity to witness, first hand, music-making on the accordion and double bass on the grounds of the Gračanica monastery on 6 September 2015, which began with men's dances (muška kola - vocal dance melodies Kolo se vije kraj manastira, Kićenice, mlada nevesto, 'Ajde Stamena, bela, rumena), and then continued with moravac. ${ }^{19}$ After the ritual ceremonies at the groom's home, which, in a reduced sense, honour only some of the parts of the formerly complex wedding ritual (with the tones of the traditional wedding song $O j$, ubavo which is performed when the 
Zakić, M. and Ranković, S.: Current Music and Dance Practice of Central Kosovo...

bride comes out of the groom's home), the already mentioned repertoire of songs and dances with the pattern of men's dances, a pop-folk music wedding party celebration followed at the local hotel, with the songs of Kosovo and Metohija dominating the repertoire; songs and dances which are common for wedding celebrations throughout Serbia, and occasionally those national, patriotic songs, dedicated to war events and praising the existence of Serbs in this territory.

For political reasons, the Albanians did not hold wedding celebrations between 1991 and 1999. According to the manager of Shota, nowadays the wedding customs are shorter, women no longer dye their hair with henna, and wedding receptions are typically held at hotels. Povin krushqit and Roke mandolina, which were formerly the two most popular songs at Albanian weddings, have been replaced, since the war, by songs about the so-called Kosovo Liberation Army, which are likewise, in the Albanian community, considered to be patriotic songs, and more recently also by a contemporary Albanian vocal repertoire, with a modern instrumental accompaniment.

Modern musical expression is especially cultivated by young members of the Romani community. An illustrative example is the vocal-instrumental group "Džimi bend" from the vicinity of Gračanica, whom we came to cooperate with through the assistance of and thanks to Edi Ibrahimi, Minority Counselor in the municipality of Gracanica. Their style is based on reinterpretations (or, more accurately, their own versions) of popular Romani, Serbian, Albanian, and Turkish songs (usually with the help of the World Wide Web) and their own melodies, which mostly feature a pervasive, hybrid character in terms of genre. The multiethnic and multi-genre repertoire of these young and talented artists, who successfully represent the music and languages of various cultures and demonstrate considerable improvisatory skill, playing mostly in faster tempi and with striking rhythms, stems from the need for a more modern and original self-assertion. ${ }^{20}$ The aspirations of Romani musicians to gain acceptance not only within their own ethnic community, but also in their wider multiethnic surroundings, as Svanibor Pettan asserts, relates more to 'the concept of the modern multicultural state than the national state, that is, to an understanding of one's region as an environment for intercultural musical encounters rather than the locale of an ethnically homogeneous musical culture'.$^{21}$

One may also note changes in the domain of traditional music and dance in the ethnic Croat community of Janjevo. The interviews with members of the Glasnović family, which we made owing to the efforts of Fr. Matej Palić, who should be credited with the survival of this community today, confirm that up until the 1990s the vocal repertory of this Croat community was multiethnic, comprising songs that one might call local Janjevo songs, as well as numerous Serbian songs from Kosovo and Metohija and Vranje, as well as a smaller num- 
ber of Macedonian and Turkish songs. It is interesting that their vocal repertory features no songs in Albanian (which does not mean that it did not feature them in the past), whereas the number of songs in Turkish comes down to only three, which contemporary singers remember only with difficulty. ${ }^{22}$ Toward the end of the $20^{\text {th }}$ century, their vocal repertory saw a gradual reduction, conditioned by a lack of performing occasions, which inevitably ushered in the process of forgetting. Although Janjevo's Romani inhabitants did celebrate St. George's Day, the feast was never jointly celebrated with the Croats. The participation of Romani people in wedding ceremonies during the $20^{\text {th }}$ century involved surladžije and gočobije, later replaced by čalga ensembles comprising three instruments: garnata (clarinet), ćemane (violin), and a devdžija - def..$^{23}$ The Croat population made music on instruments such as kafal, tambura, sarkija, đimbišs, and dalbu$k a$ (darabuka). Some of them accompanied popular dances such as musko kolo (men's dance), žensko kolo (women's dance), bugarčica, čačak, moravac, etc. ${ }^{24}$ However, the past two decades saw the total disappearance of performance practice involving those instruments.

Our conversations with the people of Janjevo gave us the impression that in the past, too, the Croat community seldom included members of other ethnic communities in their customary practices. One of the main reasons is probably that every year the men had to travel far from Janjevo in order to sell their plastic ware, leaving in the village their patriarchally brought up wives to take care of their families and tradition. ${ }^{25}$ After the departure of this population, their system of rituals and customs almost totally disappeared, because there were no people left to celebrate their traditionally established rituals. ${ }^{26}$ Today, the remaining population mark church feasts such as Christmas, Veligdan (Easter), Mali Veligdan (Low Sunday), their family patron saint, and St. George's Day.

\section{Conclusion}

The transformations observed in the music and dance heritage of different ethnic communities in central Kosovo and Metohija since the 1990s are manifested in the following relations: the national and the transnational, the professional and the amateur, the local and the regional. Their causes are numerous and may be observed in the domains of politics, ideology, sociology, culture, and art and aesthetics. During the existence of Yugoslavia, national identity was expressed in the construction of the ideological concept of Yugoslavdom, which one could broadly understand as a multiethnic principle, as opposed to the ethnic principle, established since the 1990s. The enforced communist idea of non-religiosity and its glorification of atheism likewise gained opposition in a strengthening sense of religiosity, which occurred towards the end of the $20^{\text {th }}$ century. 
Zakić, M. and Ranković, S.: Current Music and Dance Practice of Central Kosovo...

Post-socialist transition, which began in Kosovo and Metohija following the breakup of Yugoslavia and NATO bombing campaign, brought the construction of national identities ${ }^{27}$ and identity restructurings stemming from a 'conflict of divergence and opposition in ideological terms' ${ }^{28}$ This sort of 'identity comeback $^{29}$ is predicated on the opposition between $u s$ and them, ${ }^{30}$ whereby 'the identity is formed through placing Us in relation to Them, through negative and positive evaluations'. ${ }^{31}$

In the domain of professional music and dance in Kosovo and Metohija, identity opposition may be observed in the re-establishment of two folklore ensembles: the Albanian Shota and the Serbian Venac, highlighting political and ideological divisions ${ }^{32}$ By reducing their repertoire, Shota is trying to construct the identity of the 'state' that the Albanian majority has sought to create, erasing all traces of its Serbian heritage..$^{33}$ On the other hand, by similarly reducing their own repertoire and exclusively focusing on Serbian music and dance forms, $\mathrm{Ve}$ $n a c$ has given a psychological and moral boost to the ethnic Serbian population and its physical survival in Kosovo and Metohija. The Romani and Croat communities had to 'determine themselves' in relation to their religious and linguistic identities; thus the remaining Croats receive their education in the Serbian language while preserving their religious identity, while the Romani community, in religious and linguistic terms, is closer to the Albanians. ${ }^{34}$ In this instance, music and dance play the role of a subject that marks the dividing lines between different nations and has the capacity to articulate processes that shape society, ${ }^{35}$ constantly changing in the temporal dimension.

Likewise, one should not overlook the ideology of globalisation and neoliberalism, which brought numerous changes to all of Kosovo's various ethnic folk music practices, in terms of context, instrumentarium, repertory, as well as the musical and poetical texts themselves. The different aspects of expressing traditional music and dance are the reflection of political and ideological actions, i.e. 'weaving' music into society ${ }^{36}$ In other words, musical and dance practice in the post-socialist period was expressed through 'covers' of folk music with national transformations of local traditions; whereas today it is represented through the aesthetic of post-communist pop-folk.

Regarding the abovementioned, the society of Kosovo and Metohija is based on multiculturalism with a distinctive particularism, ${ }^{37}$ whose basic characteristics are 'drawn' from both the musical and dance practice of the central part of Kosovo and Metohija. 


\section{Notes}

${ }^{1}$ Under Ottoman Turkish rule, this territory was first part of the Sanjak of Skopje (administered from Skopje) and later the Vilayet of Kosovo (administered from Priština), as a first-level administrative division. Upon the establishment of the Principality of Serbia in the 1830s, the term Stara Srbija (Cmapa Србuja, Old Serbia) was gradually introduced, referring to Kosovo and Metohija, the region of Raška (Old Raška), and adjacent areas encompassing the South Morava river valley, the Šar Mountains, and western Macedonia, including the Valley of Skopje. The term Old Serbia is interpreted in historic-symbolic, geopolitical, geographical, and cultural-historical terms as referring to the territory that formed the core of Serbian statehood before the Turkish invasion. Following the Balkan Wars (1912-1913), the term Old Serbia was replaced with New Serbia, which was annexed to the Kingdom of Serbia. After World War I, from 1918 to 1929, the territory of what is today Kosovo and Metohija was part of the Kingdom of Serbs, Croats, and Slovenes (as part of the district of South Serbia) and from 1929 to 1941 to the Kingdom of Yugoslavia. Following the end of World War II, the People's Representatives' Assembly of Kosovo and Metohija voted to establish the Autonomous District of Kosovo and Metohija $(A K M O)$ within Serbia, which was later endorsed by the Constitution of the Federal People's Republic of Yugoslavia of 1946. However, the 1963 Constitution of the Socialist Federal Republic of Yugoslavia granted Kosovo and Metohija the status of an autonomous province, which remained in place until NATO's aggression and bombing of the Federal Republic of Yugoslavia in the "Noble Anvil"/“"Allied Force" campaign of 1999. Cf. Milovan Radovanović, Kosovo i Metohija: antropogeografske, istorijskogeografske, demografske i geopolitičke osnove, Beograd, Službeni glasnik, 2008, $17,21,26,41,166$, and 501.

2 The folk musical heritage of Serbia was first explored by Stevan Stojanović Mokranjac in 1896 (Стеван Ст. Мокрањац, Етномузиколоики записи, Vol. 9, in: Драгослав Девић (Ed.), Књажевац-Београд, Музичко-издавачко предузеће „Нота”, Завод за уџбенике и наставна средства, 1996), then Vladimir Đorđević in 1925 (Владимир Р. Ђорђевић, Српске народне мелодије: Јужна Србија, Скопље, Скопско научно друштво, 1928), Милоје Милојевић in 1930. (Милоје Милојевић, Народне песме и игре Косова и Метохије, in: Драгослав Девић (Ed.), Београд, Завод за упбенике и наставна средства, Карић фондација, 2004), Коста Манојловић from 1931 (his recordings, which constitute the first sound recordings of folk music made in Serbia, are kept in the Archive of the Musicology Institute of the Serbian Academy of Science and Arts and in the Archive of the Faculty of Music in Belgrade, and continue to be unavailable to the public), although this article was published: "Свадбени обичаји у Пећи", ГЕМ У Београду, Vol. VIII, in: Боривоје Дробњаковић (Ed.), Београд, Државна штампарија Краљевине Југославије, 1933, 39-51), Миодраг Васиљевић in 1946/47. године (Миодраг А. Васиљевић, Југословенски музички фолклор I: Народне мелодије које се певају на Космету, Београд, Просвета, 1950; reedition: Миодраг А. Васиљевић, Народне мелодије с Косова и Метохије, Еd. Зорислава М. Васиљевић, Београд-Књажевац, 2003). Kosovo's heritage in music and dance was also explored by Ljubica and Danica Janković in 1935 and 1939 (љубица Јанковић, "Народне игре на Косову", ГЕМ у Београду XI, 1936; Љубица и Даница Јанковић, Народне игре, Vol. II, Београд, Просвета, 1937; Љубица и Даница Јанковић, Народне игре, Vol. VI, Београд, Просвета, 1951; Љубица и Даница Јанковић, Народне игре, Vol.VII, Београд, Просвета, 1952). 
Zakić, M. and Ranković, S.: Current Music and Dance Practice of Central Kosovo...

${ }^{3}$ For more, see: Марија Думнић, "Градска музика на Косову и Метохији у истраживањима српских етномузиколога током двадесетог века", in: Драгана Радојичић (Ed.), Гласник Етнографскаи института (6/21). Београд, Етнографски институт САНУ, 2013, 83-99.

${ }^{4}$ The recordings made by Milica Ilijin, Dragoslav Dević, and Radmila Petrović in 1954 and 1955, in their field research of music and dance in Prizren and its surrounding area, are kept in the Archive of the Institute of Musicology of the Serbian Academy of Science and Arts. According to Radmila Petrović, this material includes a large number of Serbian, Turkish, and Albanian, as well as several Aromanian, Romani, and religious songs (Радмила Петровић, "Етномузиколопка истраживања на Косову", Зборник Округлог стола о научном истраживању Косова, Научни скупови САНУ, Vol.. XLI, Београд, САНУ, $1988,158,159$.) Also, there are recordings of the musical practice of ethnic Serbs living in the region of Sirinićka Župa, made by three members of the Serbian Ethnomusicological Society, Mirjana Zakić, Jasminka Dokmanović, and Svetlana Azanjac, between 2004 and 2008; this material now forms part of that Society's Archive.

A chronological overview of both published and unpublished studies of primarily Serbian music and dance heritage in individual areas of Kosovo and Metohija shows a growing scholarly focus on researching this territory starting toward the end of the $20^{\text {th }}$ century.

Милица Илијин, "Међусобни утицаји народних игара разних етничких група у Призрену", in: Vinko Z̆ganec (Ed.), Рад Конгреса фолклориста Уугославије (Вараждин, 1957), Загреб, 1959, 153-158; Радмила Петровић, “Музичка традиција у комуни Лепосавић”, Гласник музеја „Косово и Метохија”, Приштина, 1964, 435-453; Соња Шипић, Средска и Речане - музичка и орска традищија два села Средачке жупе, Београд, ФМУ, 1997. (final thesis, submitted to and defended at the Department of Ethnomusicology; in manuscript); Мирјана Закић, “Лазаричке песме из Сиринићке жупе”, in: Валентина Питулић (Ed.), Косово и Метохија у иивилизацијским токовииа, Vol. 2, Косовска Митровица, 2009, 123-136; Јована Лукић, Славске песме у долини Средњег Ибра, Београд, ФМУ, 2015. (final thesis, submitted to and defended at the Department of Ethnomusicology; in manuscript); Ђорђе Лакушић, Повратак исходииту, Београд, Службени гласник; Музеј у Приштини, 2015; Злата Марјановић, “Долете пчелка од Бога: лета̀чке/летова̀чке песме у Сиринићкој жупи”, in: Сања Радиновић and Димитрије О. Големовић (eds.), Музичка и играчка традичија мултиетничке и мултикултуралне Србије, Београд, ФМУ, 2016, 9-62; Мирјана Закић and Сања Ранковић, "Лирске љубавне песме Срба у централном делу Косова и Метохије", in: Сања Радиновић and Димитрије О. Големовић (Eds.), op. cit., 63-101.; Милена Стоиљковић, Српско певачко наслеђе призренско-подримског краја, Београд, ФМУ, 2016. (MA thesis, submitted to and defended at the Department of Ethnomusicology; in manuscript), Сања Трифуновић, Свадбене песме у околини Гюилана, Београд, ФМУ, 2016. (MA thesis, submitted to and defended at the Department of Ethnomusicology; in manuscript)

${ }^{5}$ Birthe Traerup, “Народна музика Призренске Горе”, in: Душан Недељковић (Ed.) Pad ХIV Конгреса СФЈ (Призрен, 1967), 1974, 211-223; Birthe Traerup, "Dvoglasno pjevanje u Prizrenskoj Gori”, in: Vinko Žganec (Ed.), Rad XVII Kongresa SUFJ (Poreč, 1970), Zagreb, 1972, 345-349; Трпко Бицевски, "Кон музичките карактеристика на горанското пеење", Македонски фолклор, год. VI, бр. 11, Скопје, 1973, 103-108; Birthe Trarup, "Tupan i svirala u svadbenim obredima u selu Brodu", in: Lazo Krovski and Goce Stefanovski (eds.), Pad XXV Конгреса СФJ (Берово, 1978), Скопје, 1980, 483-488; Сања Станковић, 
Индивидуално и колективно у орској и вокалној традиииј жена у Гори, Београд, ФMY, 1993. (final thesis, submitted to and defended at the Department of Ethnomusicology; in manuscript); Сања Станковић, "Основне музичко-играчке карактеристике Горе", in: Драгослав Антонијевић and Милован Радовановић (eds.), Шарпланинске жупе Гора, Средска и Опоље (антропогеографско-етнолочке, демографске, сочиолоике и културолоике карактеристике), ур. Посебна издања, Vol. 40/II, Београд, Географски институт „Јован Цвијић” САНУ, 1995, 202-213; Народната песна на Гораните, Ed. Трпко Бицевски, Народни песни, Vol. 15, Скопје, Институт за фолклор „Марко Цепенков", 2001; Веселка Тончева, Непозната Гора, София, 2012.

${ }^{6}$ Antoni Lorenc, Folklori muzikor shqiptar, Vol. I, II, III, IV, Priština 1956, 1961, 1964, 1970; Antoni Lorenc, “Osnovne karakteristike šiptarskog muzičkog folklora Kosova i Metohije”, in. Душан Недељковић (Ed.), Рad XIV Конгреса СФJ (Призрен, 1967), Београд, 1974, 109122; Rexhep Munishi, Kendimi i femrave te Podgurit, Priština, Albanološki institut, 1979.

${ }^{7}$ Svanibor Petan, Lambada na Kosovu Ed. Ivan Čolović, Beograd, Biblioteka XX vek, 2010. ${ }^{8}$ Field work was conducted under the auspices of the following projects: "The Musical Heritage of Central Kosovo and Metohija" (2005), funded by the Ministry of Culture and Information of the Republic and Serbia, and "The Music and Dance Tradition of Multiethnic and Multicultural Serbia" (no. 177024, Faculty of Music), supported by the Ministry of Education, Science, and Technological Development of the Republic of Serbia.

${ }^{9} \mathrm{Cf}$ : Јован Ђ. Марковић, Географске области СФРЈ, Београд, Универзитет у Београду, Грађевинска књига, 1970, 418.

${ }^{10}$ Саша Б. Бован, "Косово - идеолошки полигон новог милитаристичког хуманизма", in: Урош Шуваковић (Ed.), Косово и Метохија у цивилизачијским токовииа (међународни тематски зборник), Vol. 4 (Социологија и друге друштвене науке), Косовска Митровица, Универзитет у Приштини, Филозофски факултет, 2010, 144.

${ }^{11}$ Ibid.; Михаило Марковић, "Косово и европска цивилизација", in: Урош Шуваковић (Ed.), op. cit., bb-bb?

${ }^{12}$ According to the latest statistical data, the ethnic makeup of the population of Kosovo and Metohija is " $89.5 \%$ Albanian, $6.3 \%$ Serb, and $4.2 \%$ other, that is, Romani, Turkish, Ashkali, and Gorani..."; Коста Гаљак, "Демографске последице исељавања српског и осталог неалбанског становништва на Косову и Метохији под притиском албанских националиста и сепаратиста", in: Урош Шуваковић (Ed.), op. cit., bb-bb? See also Снежана Миливојевић, "Промена етничке структуре становништва на Косову и Метохији", in: Урош Шуваковић (Ed.), op. cit., bb-bb? Саша Милосављевић, "Српско становништво на Косову и Метохији након 1999. године", in: Урош Шуваковић (Ed.), op. cit., bb-bb?

${ }^{13}$ According to written sources, Catholic communities in Janjevo are mentioned as early as the $14^{\text {th }}$ century, in documents prepared for Pope Benedict XI (Nikola Čolak, Ive Mažuran, in: Antun Glasnović (Ed.), Janjevo, sedam stoljeća opstojnosti Hrvata na Kosovu, Zagreb, Udruga „Janjevo", Matica hrvatska, 2000, 19). Writing about Janjevo, Branislav Nušić stated that the village was first mentioned as early as the Middle Ages, when it was populated by Saxons, "Latins" (Latini, Латинu), and merchants from Dubrovnik (Бранислав Нушић, in: Светлана Велмар-Јанковић (Ed.), Косово, Vol. II, Београд, Просвета, Библиотека „Баштина", 1986, 235-237). He referred to the inhabitants of this village as "Catholic Serbs" who called themselves "Latins" (Ibid., 237). However, other sources describe the in- 
Zakić, M. and Ranković, S.: Current Music and Dance Practice of Central Kosovo...

habitants of Janjevo as ethnic Croats (Nikola Čolak, Ive Mažuran, op. cit.,35), and they are thus identified, which has been corroborated by more recent research, last conducted in 2016. According to the Catholic parish priest of Janjevo, Fr. Matej Palić, the village is currently populated by 300 people of Romani and Turkish ethnic stock each, while 650 formerly Croat households are completely empty. Until the $1990 \mathrm{~s}$, there were between 4,000 and 5,000 Catholic Croats living in Janjevo. Our field research in Janjevo was made possible by Fr. Matej Palic and his personal efforts in reaching out to the local community.

${ }^{14}$ During the period mentioned above, these instruments replaced other instruments that were once customary in everyday life, such as duduče, duduk, gajde [bagpipes], as well as $d v o-$ jnica (double flute), and kaval. For more, see Мирјана Закић и Сања Ранковић, “Лирске љубавне песме Срба у централном делу Косова и Метохије”..., 67.

${ }^{15}$ For more on the concept of alaturka, see Svanibor Pettan, "Alaturka - alafranga continuum in Balkan music and ethnomusicology", Research of dance and music on the Balkans (International Symposium Brčko, Decembre 06-09 2007), Brčko: International Musical Society, Musicological Society of RS Banja Luka, Musicological Soceity FBiH Sarajevo, Association for Fostering of the Serb Cultural/Historical Heritage "Baštinar" Brčko, 2007, 89-98.

${ }^{16}$ For more on the genesis of talava and its transformation in gender and musical terms, see Svanibor Petan, Muško i žensko u kulturi i muzici Roma na Kosovu, op. cit., 95-103; Carol Silverman, "Musical styles and genres", Romani Routes (Cultural Politics \& Balkan Music in the Diaspora), Oxford, University Press, 2012, 21-37,36-37.

17 The statement was made during an interview with Vebija Tairi, Vezira Tairović, Timeti Kimeti, and Džanera Čakatoli, conducted in Gračanica.

${ }^{18} \mathrm{Ibid}$.

${ }^{19}$ According to matching testimonies from the locals, the "men's dances" refer to dances performed according to the same three-bar pattern, which, according to choreology literature, belongs to the lako kolo ("light" or "easy dance") type. The locals ascribe their gender attribution to the former practice of gender-specific dances, which was replaced, over the course of the $20^{\text {th }}$ century, by men and women's equal participation in those dances. The "men's dances" were followed by moravac, čačak, and Žikino kolo, as a dance repertory that is typical of those parts. For more on this, see also Љубица С. и Даница С. Јанковић, Народне игре, књ. II, Београд, Просвета, 1937, 36.

${ }^{20}$ In ethnomusicological studies, scholars often emphasise the inclination of Romani musicians to pursue the new, the urban, and the international, as well as to assert themselves in modern musical genres. For instance, see Радмила Петровић, "Народна музика Југославије - процес акултурације”, Звук 2, 1974, 157; Svanibor Petan, „Susret sa "unutrašnjim drugima'. Slučaj romskih muzičara iz bivše Jugoslavije”, in: Svanibor Petan, Lambada na Kosovu, op. cit., 17; Carol Silverman, "Musical styles and genres", Romani Routes (Cultural Politics \& Balkan Music in Diaspora), Oxford, Oxford University Press, 2012, 21-37.

${ }^{21}$ Svanibor Pettan, "Susret sa 'unutrašnjim drugima'. Slučaj romskih muzičara iz bivše Jugoslavije", Lambada na Kosovu, op. cit., 20, 21.

${ }^{22}$ Before the NATO campaign, some of the Croats in the area were multilingual, speaking not only their own language, but also Turkish and Albanian.

${ }^{23}$ Cf: Nikola Čolak, Ive Mažuran, op. cit., 225.

${ }^{24}$ Mention of muško oro and žensko oro merely attest to the continuity of these dances in this area throughout the $20^{\text {th }}$ century (Ibid., 226). 
${ }^{25}$ The big Croat families of the past, where women had as many as ten children, are a rare occurrence these days, mostly for economic reasons. Even interethnic marriages were rare, while marriages with members of the Muslim community were especially undesirable.

${ }^{26}$ The Glasnovic family could not recall the last time there was a wedding in the village.

${ }^{27}$ In contemporary political science, national identity is viewed as a subjective dimension: Jasna Milošević-Đorđević, "Jedan pokušaj klasifikacije teorijskih razmatranja nacionalnog identiteta", Psihologija, Vol. 36 (2), 2003, 127.

${ }^{28}$ In the 1990s, following the break-up of Yugoslavia, this phenomenon also characterised the Croat ethnic community: Naila Ceribašić, "Glazbeni repertoar na svadbama $u$ slavonskoj podravini (istočna Hrvatska) prije i poslije političkih promjena u Hrvatskoj 1990. godine", Arti musices, 24:2, 1993, 224; Naila Ceribašić, "Heritage of the Second World War in Croatia: Identity imposed upon and by music", in: Svanibor Pettan (Ed.), Music, politics, and war: views from Croatia, Zagreb, Institute of Ethnology and Folklore Research, 1998, 109-129, 110.

${ }^{29}$ Ivan Člović used the term "identity comeback" in his discourse on the construction of Serbian identity and national culture during the 1980s and '90s (Ivan Colović, Rastanak $s$ identitetom, Belgrade, Biblioteka XX vek, 2014, 168). However, the concept is applicable to members of other ethnic communities in Kosovo and Metohija.

${ }^{30}$ Cf: Fredrik Bart, "Etničke grupe i njihove granice", in: F. Putinja, Ž. Stref-Fenar (Eds) Teorije o etnicitetu. Beograd, Biblioteka XX vek, 1997, 216.

${ }^{31}$ Naila Ceribašić, op. cit., 110.

${ }^{32}$ Within Kosovo and Metohija, their artistic repertoire is geared exclusively toward communicating with their own people.

${ }^{33}$ This phenomenon of specific ethnic, religious, and cultural relations is typical of postwar cultural occurrences, which likewise took place in other republics of former Yugoslavia during the 1990s: Naila Ceribašić, "Glazbeni repertoar na svadbama u slavonskoj podravini" ..., 225; Mirjana Laušević, “The Ilahiya as a Simbol of Bosnian Muslim", in: Mark Slobin (Ed.), Returning culture, Musical Changes in Central and Estern Europe, Duke University Press Durham and London, 1996, 117-135. Svanibor Pettan, "Music, politics, and war in Croatia in the 1990s: an introduction", in: Svanibor Pettan, "Music, politics, and war in Croatia in the 1990s: an introduction", in: Svanibor Pettan (Ed.), op. cit., 9-27; Naila Ceribašić, op. cit.; Tvrtko Zebec, "Dance vents as political rituals for expression of identities in Croatia in the 1990s", in: Svanibor Pettan (Ed.), op. cit., 151-162; Miroslava Hadžihusejnović-Valašek, "The Osijek wartime music scene 1991-1992", in: Svanibor Pettan (Ed.), op. cit., 163-184.

${ }^{34}$ The religious factor is a culturally potent subject and it is therefore hardly surprising that religion is considered institutionally more powerful than language (which applies to Kosovo and Metohija as well). Rogers Brubaker, "Language, religion and the politics of difference", Nations and nationalism, journal of the association for the study of ethnicity and nationalism. Vol. 19 (1), 2013, 3.

${ }^{35}$ Philip V. Bohlman, The Music of European Nationalism: Cultural Identity and Modern History. Santa Barbara, Calif, ABC-CLIO, 2004. 12.

${ }^{36}$ Martin Stokes, "Introduction: Ethnicity, Identity and Music", Ethnicity, Identity and Music, The Musical Construction of Place, Berg, University of Oxford, 1994, 2-3.

${ }^{37}$ Nikola Božinović, Kultura i identiteti na Balkanu, Niš, Filozofski fakultet/Centar za sociološka istraživanja, 2007, 32-34 
Zakić, M. and Ranković, S.: Current Music and Dance Practice of Central Kosovo...

\section{References}

Bart, Frederik: "Etničke grupe i njihove granice", in: F. Putinja, Ž. Stref-Fenar (Eds.), Teorije o etnicitetu. Beograd: Biblioteka XX vek, 1997.

Бицевски, Трпко: „Кон музичките карактеристика на горанското пеење”, in: Македонски фолклор. Year VI, No. 11. Скопје: 1973, 103-108.

---: (Ed.): Народната песна на Гораните. Народни песни, Vol. 15. Скопје: Институт за фолклор „Марко Цепенков”, 2001.

Bohlman, Philip V.: The Music of European Nationalism: Cultural Identity and Modern History. Santa Barbara - Calif: ABC-CLIO, 2004.

Brubaker, Rogers: "Language, religion and the politics of difference", in: Nations and nationalism, journal of the association for the study of ethnicity and nationalism. Vol. 19 (1), 2013, 1-20.

Ceribašić, Naila: "Glazbeni repertoar na svadbama u slavonskoj podravini (istočna Hrvatska) prije i posle političkih promjena u Hrvatskoj 1990. godine", in: Arti musices. No. 24:2, 1993.

---: "Heritage of the Second World War in Croatia: Identity imposed upon and by music", in: Svanibor Pettan (Ed.): Music, politics, and war: views from Croatia. Zagreb: Institute of Ethnology and Folklore Research, 1998, 109-129.

Čolović, Ivan: Rastanak s identitetom. Beograd: Biblioteka XX vek, 2014.

Думнић, Марија: „Градска музика на Косову и Метохији у истраживањима српских етномузиколога током двадесетог века", in: Драгана Радојичић (Ed.), Гласник етнографског института. №. 6/21. Београд: Етнографски институт САНУ, 2013, 83-99.

Ђорђевић, Владимир: Српске народне мелодије: Јужна Србија, Скопље: Скопско научно друштво, 1928.

Glasnović, Antun (Ed.): Janjevo, sedam stoleća opstojnosti Hrvata na Kosovu. Zagreb: Udruga „Janjevo”, Matica Hrvatska, 2000.

Hadžihusejnović-Valašek, Miroslava, "The Osijek wartime music scene 1991-1992”, in: Svanibor Pettan (Ed.): Music, politics, and war: views from Croatia. Zagreb: Institute of Ethnology and Folklore Research, 1998, 163-184.

Илијин, Милица: „Међусобни утицаји народних игара разних етничких група у Призрену", in: Vinko Žganec (Ed.), Рад конгреса фолклориста Југославије (Вараждин, 1957). Загреб, 1959, 153-158.

Јанковић, Даница и Љубица: Народне игре. Vol. II. Београд: Просвета, 1937.

---: Народне игре. Vol. VI. Београд: Просвета, 1951.

---: Народне игре. Vol. VII. Београд: Просвета, 1952.

Јанковић, Љубица: „Народне игре на Косову”, ГЕМ у Београду. Vol. XI. Београд: Државна штампарија Краљевине Југославије, 1936.

Лакушић, Ђорђе: Повратак исходииту. Београд: Службени гласник, 2015.

Laušević, Mirjana: "The Ilahiya as a Symbol of Bosnian Muslim", in: Mark Slobin (Ed.), Returning culture, Musical Changes in Central and Eastern Europe. Durham and London: Duke University Press, 1996, 117-135. 
Lorenc, Antoni: Folklori muzikor shqiptar. Vols. I, II, III, IV. Priština: „Milladin Popoviq”, 1956, 1961, 1964, 1970.

---: „Osnovne karakteristike šiptarskog muzičkog folklora Kosova i Metohije”, in: Душан Недељковић (Ed.), Рад ХIV конгреса СФЈ (Призрен 1967). Београд: 1974, 109122.

Лукић, Јована: Славске песме у долини средњег Ибра. Final thesis manuscript. Београд: ФМУ, 2015.

Манојловић, Коста: „Свадбени обичаји у Пећи”, in: Боривоје Дробњаковић (Ed.), ГЕМ y Београду. Vol. VIII. Београд: Државна пттампарија Краљевине Југославије, 1933, 39-51.

Марјановић, Злата: „Долете пчелка од Бога: летачке/летовачке песме у Сиринићкој жупи", in: Сања Радиновић and Димитрије О. Големовић (Eds.), Музичка и играчка традичија мултиетничке и мултикултуралне Србије. Београд: ФМУ, 2016, 9-62.

Марковић, Јован Ђ.: Географске области СФРЈ. Београд: Универзитет у Београду, Грађевинска књита, 1970.

Милојевић, Милоје: Народне песме и игре Косова и Метохије, in: Драгослав Девић (Ed.). Београд: Завод за уџбенике и наставна средства, Карић фондација, 2004.

Milošević-Đorđević, Jasna: „Jedan pokušaj klasifikacije teorijskih razmatranja nacionalnog identiteta", in: Psihologija. Vol. 36 (2), 2003.

Мокрањац, Стеван Ст.: Етномузиколошки записи. Vol. 9, in: Драгослав Девић (Ed.). Књажевац - Београд: Музичко-издавачко предузеће „Нота”, Завод за уџбенике и наставна средства, 1996.

Munishi, Rexhep: Kendimi i femrave te Podgurit. Priština: Albanološki institut, 1979.

Petan, Svanibor: Lambada na Kosovu. Beograd: Biblioteka XX vek, 2010.

---: "Music, politics, and war in Croatia in the 1990s", in: Svanibor Pettan (Ed.): Music, politics, and war: views from Croatia. Zagreb: Institute of Ethnology and Folklore Research, 1998, 9-27.

---: „Muško i žensko u kulturi i muzici Roma na Kosovu”, in: Research of dance and music on the Balkans (International symposium Brcko, December 06-09, 2007). Brčko: International Musical Society, Musicological Society of RS Banja Luka, Musicological Society FBiH Sarajevo, Association for Fostering of Serb Cultural/Historical Heritage „Baštinar” Brčko, 2007, 95-103.

---: "Alaturka - alafranga continuum in Balkan music and ethnomusicology", in: Research of dance and music on the Balkans (International symposium Brčko, December 06-09. 2007). Brčko: International Musical Society, Musicological Society of RS Banja Luka, Musicological Society FBiH Sarajevo, Association for Fostering of Serb Cultural/Historical Heritage "Baštinar" Brčko, 2007, 89-98.

Петровић, Радмила: „Музичка традишија у комуни Лепосавић”, Гласник музеја „Косово и Метохија". Приштина, 1964, 435-453.

---: „Народна музика Југославије - процес акултурације” in: Звук. No. 2. Sarajevo, 1974.

---: „Етномузиколошка истраживања на Косову”, Зборник округлог стола о научном истраживању Косова. Vol. XLII. Београд: САНУ, 1988. 
Zakić, M. and Ranković, S.: Current Music and Dance Practice of Central Kosovo...

Radovanović, Milovan: Kosovo i Metohija: antropogeografske, istoriografske, demografske $i$ geopolitičke osnove. Beograd: Službeni glasnik, 2008.

Silverman, Carol: "Musical styles and genres" in: Roamani Routes (Cultural Politics \& Balkan Music in the Diaspora). Oxford: Oxford University Press, 2012, 21-37.

Станковић, Сања: Индивидуално и колективно у орској и вокалној традицији жена у Гори. Final thesis manuscript. Београд: ФМУ, 1993.

---: „Основне музичко-играчке карактеристике Горе”, in: Драгослв Антонијевић and Милован Радовановић (Eds.), Шарпланинске жупе Гора, Средска и Опоље (антропогеографско-етнолочке, демографске, сочиолочке и културолошке карактеристике). Посебна издања, Vol. 40/II. Београд: Географски институт „Јован Цвијић” САНУ, 1995, 202-213.

Стојиљковић, Милена: Српско певачко наслеђе призренско-подрииског краја. MA thesis manuscript. Београд: ФМУ, 2016.

Шипић, Соња: Средска и Речане - музичка и орска традичија два села Средачке жупе. Final thesis manuscript. Београд: ФМУ, 1997.

Шуваковић, Уропп (Еd.): Косово и Метохија у цивилизачијским токовима (међународни тематски зборник). Vol. 4 (Социологија и друге друштвене науке). Косовска Митровица: Универзитет у Приштини, Филозофски факултет, 2010.

Тончева, Веселка: Непозната Го̀ра. София, 2012.

Traerup, Birthe: „Народна музика призренске горе”, in: Душан Недељковић (Ed.), Рad XIV конгреса СФЈ (Призрен, 1967). Београд, 1974, 211-223.

---: „Dvoglasno pjevanje u Prizrenskoj Gori", in: Vinko Žganec (Ed.), Rad XVII kongresa SUFJ (Poreč, 1970). Zagreb, 1972, 345-349.

---: „,Tupan i svirala u obredima u selu Brodu”, in: Lazo Krovski and Goce Stefanovski (Eds.), Рад XXV конгреса СФЈ (Берово 1978). Скопје: 1980, 483-488.

Трифуновић, Сања: Свадбене песме у околини Гњилана. MA thesis manuscript. Белград: ФМУ, 2016.

Васиљевић, Миодраг А.: Народне мелодије са Косова и Метохије. Београд Књажевац: Нота, 2003.

Велмар-Јанковић, Светлана (Ed.), Косово. Vol. II. Београд: Просвета, 1986.

Закић, Мирјана: „Лазаричке песме из Сиринићке жупе”, in: Валентина Питулић (Ed.), Косово и Метохија у цивилизачијскии токовима. Vol. 2. Косовска Митровица, 2009, 123-136.

Закић, Мирјана and Сања Ранковић: „Лирске љубавне песме Срба у централном делу Косова и Метохије", in: Сања Радиновић and Димитрије О. Големовић (Eds.), Музичка и играчка традичија мултиетничке и мултикултуралне Србије. Београд: ФМУ, 2016, 63-101.

Zebec, Tvrtko, "Dance vents as political rituals for expression of identities in Croatia in the 1990s: an introduction", in: Svanibor Pettan (Ed.): Music, politics, and war: views from Croatia. Zagreb: Institute of Ethnology and Folklore Research, 1998, 151-162. 